9. Computerworld Polska. Magazyn menedżerów i informatyków. 11. Warszawa: IDG Poland.2017.

10. Нижник В.М., Терехов Д.С. Еволюція розвитку інформаційних систем та інформаційних технологій в управлінні підприємствами. Економічні науки. Вісник Хмельницького національного університету № 5 ‘2009. Т. 2.С.220-223.

\title{
References:
}

1.Knott, P. (2006). A typology of strategy tool applications. Management Decision. 44(8). 1090-1105. doi: $10.1108 / 00251740610690630$.

2.Sauter, V. L. (2010). Decision Support Systems for Business Intelligence (2nd Edition). USA: John Wiley \& Sons.

3.Suarez, E. R. (2016). The Strategic Management Frameworks and the Delta Model: Putting Customers Before Products. doi: 10.13140/RG.2.1.1847.4643.

4.Wang, J. i Radosevich, D. J. (2010). Decision Support System. W: M. G. Hunter, (Eds.), Strategic Information Systems: Concepts, Methodologies. Tools and Applications. 2010. P. 114-121.

5.Watson, H. J. (2012). The Requirements for Being an Analytics-Based Organization. Business Intelligence Journal.17(2), 46.

6.Chmielarz, W. (2013). Zarządzanie projektami@ rozwój systemów informatycznych zarządzania. Warszawa: Wydawnictwo Naukowe Wydziału Zarzadzania Uniwersytetu Warszawskiego.

7.Chomuszko, M. (2016). System ERP, Dobre praktyki wdrożeń. Warszawa: Wydawnictwo Naukowe PWN.

8.Lynch, R. (2015). Strategic Management (7th Edition). Wielka Brytania: Pearson Education Limited.

9.Computerworld Polska (2017). Magazyn menedżerów i informatyków.11. Warszawa: IDG Poland.

10. Nyzhnyk V.M., Terekhov D.S.Evoliutsiia rozvytku informatsiinykh system ta informatsiinykh tekhnolohii v upravlinni pidpryiemstvamy. [Evolution of development of information systems and information technologies in enterprise management] Ekonomichni nauky. Visnyk Khmelnytskoho natsionalnoho universytetu. № 5 ‘2009. T. 2.S.220-223.

Дата подання публікації 10.10.2021p.

УДК 339.165.5:330.341.1

Рудь Н.Т., д.е.н., професор

Rud N. Doctor of Economic Sciences, Professor https://orcid.org/0000-0002-9040-146X

\section{БРЕНД ЯК НЕМАТЕРІАЛЬНИЙ АКТИВ В ІННОВАЦІЙНІЙ ЕКОНОМІЦІ}

\author{
Луиьький національний технічний університет
}

В статті показано, що в сучасному конкурентному середовищі продовжується боротьба брендів, а не товарів, за їхнє місце у свідомості споживачів. Підприємства не формують потенціал стратегічного розвитку за рахунок бренда як нематеріального активу.

Виділено нові категорії споживачів: людям необхідні прості, зручні і компактні речі (маленька квартира); екологи - обмеження споживання і збереження природи; екоактивісти - зниження шкідливих викидів в атмосферу (зменшення кількості відряджень, проведення Zoom - конференцій); питання харчування - більшість людей хочуть стати ваганами чи вегетаріанцями, їсти більше овочів і фруктів; прихильники повторного використання ресурсів, переробки матеріалів.

Деталізовані визначальні характеристики поняття «бренд». Наведені підходи вчених до формулювання даного поняття. Запропоновано авторське визначення бренду як інтелектуальної власності (нематеріального активу), яка має певну вартість та відображає особливості товару, його унікальність і створює незабутнє враження у споживача.

Виокремлено сфери сучасного використання бренду. Відмічено, що бренди створюються за допомогою інновацій і процвітають за наявності безперервного потоку інновацій. Саме нововведення викликають тимчасову конкурентну перевагу, оскільки інноваційна продукція викликає у споживачів відчуття, що бренд дійсно є лідером і спрямований на задоволення потреб споживачів.

Процес бренд-менеджменту підприємства має спрямовуватись на зростання його сили та вартості. За цими основними характеристиками бренд-менеджменту можливо здійснити оцінку ефективності формування та використання брендів та марочного капіталу підприємства.

Використання нематеріальних активів зростає з переходом конкуренції в нецінову форму. Для їх ефективного використання необхідно впроваджувати принципово нові способи обліку. Питання оцінки та відображення нематеріальних активів в обліку залишається до цього часу дискусійним.

Доведено, що не існує реальної моделі обчислення вартості бренду; головним фактором недосконалості оцінки вартості бренду є відірваність його від звітностей компаній та не відображення таких нематеріальних активів на балансі компаній; форс-мажорні обставини мають безпосередній вплив на вартість матеріальних активів, в той час як нематеріальні активи не втрачають свою вартість.

Ключові слова: активи, нематеріальні активи, інноваиія, бренд-менеджмент, вартість. 


\title{
BRAND AS AN INTANGIBLE ASSET IN INNOVATIVE ECONOMY
}

\author{
Lutsk National Technical University
}

The article shows that in today's competitive environment, the struggle of brands, rather than goods, for their place in the minds of consumers. Enterprises do not form the potential of strategic development at the expense of the brand as an intangible asset.

New categories of consumers have been identified: people need simple, convenient and compact things (small apartment); ecologists - restriction of consumption and preservation of nature; eco-activists - reduction of harmful emissions into the atmosphere (reduction of business trips, holding Zoom conferences); nutrition issues most people want to become vagans or vegetarians, eat more vegetables and fruits; supporters of reuse of resources, processing of materials.

Detailed defining characteristics of the concept of "brand". The author's definition of a brand as intellectual property (intangible asset), which has a certain value and reflects the features of the product, its uniqueness and creates an unforgettable impression on the consumer.

The spheres of modern use of the brand are singled out. It is noted that brands are created through innovation and thrive in the presence of a continuous flow of innovation. It is the innovations that cause a temporary competitive advantage, as innovative products give consumers the feeling that the brand is truly a leader and is aimed at meeting the needs of consumers.

The process of brand management of the enterprise should be aimed at increasing its strength and value. According to these main characteristics of brand management, it is possible to assess the effectiveness of the formation and use of brands and brand capital of the enterprise.

The use of intangible assets increases with the transition of competition to non-price form. For their effective use it is necessary to introduce fundamentally new methods of accounting. The issue of valuation and reflection of intangible assets in accounting remains controversial.

It is proved that there is no real model for calculating the value of a brand; the main factor in the imperfection of the assessment of the value of the brand is its isolation from the reporting of companies and the reflection of such intangible assets on the balance sheets of companies; force majeure has a direct effect on the value of tangible assets, while intangible assets do not lose their value.

Key words: assets, intangible assets, innovation, brand management, value.

Постановка проблеми у загальному вигляді i ïі зв'язок з важливими науковими та практичними завданнями. Ми живемо в епоху особистих брендів, оскільки довіряють не компанії, а особисто вам. Для чого потрібен бренд? Це комерційна вигода, інтерес потенційних співробітників, пошук стратегічно вигідних партнерів, інтерес і довіра потенційних інвесторів. У компанії має бути своє обличчя (свій герой). Тенденція становлення брендів в управлінській діяльності на підприємствах триває досить інтенсивно з урахуванням того, що в сучасному конкурентному середовищі продовжується боротьба брендів, а не товарів, за їхнє місце у свідомості споживачів. Підприємства насамперед зосереджені на вирішенні проблем розвитку, пов'язаних з ефективним використанням матеріальних активів, а формування потенціалу стратегічного розвитку за рахунок бренда як нематеріального активу підприємства залишається поза їхньою увагою.

Аналіз останніх досліджень, у яких започатковано вирішення проблеми. В наукових працях велика увага приділяється питанням формування концепції брендменеджменту, в основі якої знаходиться формування та управління брендом товару. Зокрема, Аакер Д.А., Багієв Г.Л., Балабанова Л.В., Бойєт Д., Ванекен Б., Вінсент Л., Герман Д., Годін О.М., Головлева О.Л., Девіс С., Должанський І.З., Домнін В.Н., Еллвуд А., Ле Пла Ф., Макашев М.О., Макнеллі Д., Нільсон Т., Прингл А., Рожков І.Я., Садєков А.А., Шарков Ф.І., Шубін О.О., Шульгіна Л.М. та ін. Питання бренду як нематеріального активу ними практично не розглядалося і комплексно не досліджувалося. Таким чином, виникає необхідність дослідження цього питання.

Ціль статті - обгрунтування важливості бренду для результативної діяльності підприємства.

Виклад основного матеріалу дослідження 3 повним обгрунтуванням отриманих наукових результатів. Самі великі гроші в брендах. Бренд - це репутація, обіцянка клієнтам: який результат вони одержать сьогодні, завтра і в інший любий день. 
У кожного бренду має бути велика ідея, те, що він обіцяє своїм клієнтам (Volvo гарантує клієнтам безпеку, Disney - радість і щастя). Не робіть клієнта задоволеним, приводьте його у захват, зробіть його щасливим.

Котлер Ф. відмічає, що маркетинг постійно змінюється, незмінним залишається робота успішних компаній на те, щоб зробити клієнта щасливим. Вони розуміють, що потрібно людям і дають їм це. В даний час можемо виділити нові категорії споживачів:

1) людям необхідні прості, зручні і компактні речі (маленька квартира);

2) екологи - обмеження споживання і збереження природи;

3) екоактивісти - зниження шкідливих викидів в атмосферу (зменшення кількості відряджень, проведення Zoom - конференцій);

4) питання харчування - більшість людей хочуть стати ваганами чи вегетаріанцями, їсти більше овочів і фруктів;

5) прихильники повторного використання ресурсів, переробки матеріалів.

Необхідно переформатувати комунікацію 3 клієнтами: проаналізувати проблеми клієнтів в нових реаліях і допомогти їм їх вирішити.

Існують різні підходи щодо визначення сутності «бренд». Розглянемо детальніше визначальні характеристики поняття «бренд» у таблиці 1.

Таблиця 1

Визначальні характеристики поняття «бренд»

\begin{tabular}{|c|c|}
\hline Автор & Змістовна характеристика бренду - це: \\
\hline Д. Огілві & $\begin{array}{l}\text { - «невловима сума властивостей продукту (сукупність вражень, які спрямовуються } \\
\text { на споживачів): його імені, упаковки й ціни, історії, репутації і способу рекламування». }\end{array}$ \\
\hline $\begin{array}{l}\text { Співробітники } \\
\text { агентства Ogilvy \& } \\
\text { Mather }\end{array}$ & $\begin{array}{l}\text { - «те, що споживачі відчувають стосовно продукту; це прихильність до нього; ті } \\
\text { персональні характеристики, які вони приписують продукту, довіра і відповідальність, } \\
\text { які вони відчувають до нього». }\end{array}$ \\
\hline Ю. Любашевський & $\begin{array}{l}\text { - «слово, назва, вираз, знак, символ чи дизайнерське рішення або ж їх комбінація } \\
\text { для позначення товару чи послуги конкретного виробника». }\end{array}$ \\
\hline $\begin{array}{l}\text { Американська асоціація } \\
\text { маркетингу - АМА }\end{array}$ & $\begin{array}{l}\text { - «назва, термін, знак, символ або дизайн, а також їх комбінації, які призначені для } \\
\text { ідентифікації товарів або послуг одного продавця або групи продавців для відмінності їх } \\
\text { товарів або послуг конкурентів». }\end{array}$ \\
\hline Landor Associates & $\begin{array}{l}\text { - «сума всіх характеристик, матеріальних або нематеріальних, яка робить комерційну } \\
\text { гопозицію унікальною». }\end{array}$ \\
\hline P. Kox & $\begin{array}{l}\text { - «візуальний символ і / або ім'я, які надаються товару або послузі організацією, і які } \\
\text { дозволяють відрізнити його від товарів-конкурентів і завіряють споживача в тому, що } \\
\text { якість товару буде незмінно високою». }\end{array}$ \\
\hline Martin E., Thoma Creaive & $\begin{array}{l}\text { - «сума всього, що люди знають, думають, відчувають щодо компанії, послуги або } \\
\text { товару». }\end{array}$ \\
\hline Д. Траут & - «гарна ідея, плюс проникнення у свідомість споживачів». \\
\hline B. $\mathrm{N}$ & $\begin{array}{l}\text { - «сукупність уявлень і очікувань споживача щодо конкретного «орендованого» } \\
\text { товару, тоді як торгова марка - це окремі вербальні і візуальні елементи фірмового } \\
\text { стилю, що дозволяють споживачеві ідентифікувати товар і виділяти його з товарної } \\
\text { групи». }\end{array}$ \\
\hline І. Соловйова & - «сукупність вражень, що викликаються у споживача тієї чи іншої торгової марки». \\
\hline М. Яндієв & $\begin{array}{l}\text { - «явище, коли має місце масове виробництво однотипних емоцій як самостійного } \\
\text { товару, призначеного для розповсюдження». }\end{array}$ \\
\hline $\begin{array}{l}\text { Л. Врис, С. Генсл } \\
\text { П. Леефланг }\end{array}$ & $\begin{array}{l}\text { - «запатентований візуальний, емоційний, раціональний і культурний образ, який } \\
\text { асоціюється з компанією або товаром». }\end{array}$ \\
\hline $\begin{array}{l}\text { С. Люпін, Сяона Чжен, } \\
\text { Мен Су, Л. Робін } \\
\text { Келлер }\end{array}$ & $\begin{array}{l}\text { - «переконлива обіцянка якості, обслуговування та цінності на тривалий період, яка } \\
\text { підтверджується випробуванням товару, повторними покупками та задоволенням від } \\
\text { використання». }\end{array}$ \\
\hline Д. Діон і С. Борраз & $\begin{array}{l}\text { - «невловима сума властивостей товару: його імені, упакування, ціни, його історії, } \\
\text { репутації та способу рекламування. Бренд також є комбінацією враження, яку він } \\
\text { справляє на споживачів, і результатом їх досвіду у використанні бренду» }\end{array}$ \\
\hline Авторське визначення & $\begin{array}{l}\text { - інтелектуальна власність (нематеріальний актив), яка має певну вартість та відображає } \\
\text { особливості товару, його унікальність і створює незабутнє враження у споживача. }\end{array}$ \\
\hline
\end{tabular}

Примітка. Сформовано автором на основі джерел [1-12] 
Аналізуючи дослідження різних учених, приходимо до думки, формування та управління брендом - це процес, який створює щось важливе та цінне для споживачів, що виражається в атрибутах і комунікаціях, і дозволяє правильно розпізнавати товар (послугу) та мати довгочасну купівельну перевагу.

Важливість поняття бренду на сучасному етапі економічного розвитку та економічної інтеграції відображено в табл. 2 [13].

Таблиця 2

Сфери сучасного використання бренду

\begin{tabular}{|l|l|}
\hline \multicolumn{1}{|c|}{ Фінансова } & \multicolumn{1}{|c|}{ Не фінансова } \\
\hline Планування злиттів та поглинань & Управління брендом \\
\hline Податкове планування & Формування портфелів брендів \\
\hline $\begin{array}{c}\text { Бухгалтерський облік нематеріальних } \\
\text { активів і звітність }\end{array}$ & Стратегічне маркетингове планування \\
\hline Ліцензування та франчайзинг & Внутрішні комунікації \\
\hline Забезпечення кредитів & Складання маркетингового бюджету \\
\hline Стосунки з інвесторами & Правові документи \\
\hline
\end{tabular}

Зазвичай, управління брендом прирівнюється до управління комунікаціями, хоча бренди створюються за допомогою інновацій і процвітають за наявності безперервного потоку інновацій. Це пояснюється тим, що нововведення викликають тимчасову конкурентну перевагу. Інноваційна продукція викликає у споживачів відчуття, що бренд дійсно є лідером і спрямований на задоволення потреб споживачів.

Процес бренд-менеджменту підприємства має спрямовуватись на зростання його сили та вартості. За цими основними характеристиками бренд-менеджменту можливо здійснити оцінку ефективності формування та використання брендів та марочного капіталу підприємства. Детально етапи процесу формування і використання бренду досліджено в роботі [14]. Автор відмічає, що «чим триваліше життєвий цикл бренда, тим ефективніше будуть витрати на його розробку, тестування, оскільки тоді його питома вартість буде знижуватись» [14, с. 391].

Розвиток технології формування бренду торгівельних підприємств в Україні виявив нерівномірність іï впровадження в діяльність, що пов'язано, перш за все, 3 відсутністю ефективних науково-обгрунтованих, адаптованих до вітчизняних ринкових умов підходів щодо формування та управління бренд-менеджментом підприємства.

Конкуренція на споживчому ринку актуалізує значимість управління торговими марками. Оскільки ринок товарів і послуг стрімко зростає, то необхідно активізувати увагу потенційних споживачів. 3 економічної точки зору «для споживачів вибір товару чи послуги відомого бренду скорочує витрати, пов'язані із цим процесом. Сюди відносяться витрати вибору (час, витрачений споживачем на придбання), асортимент товару чи послуг, з якими повинен ознайомитися споживач» $[15$, с. 369$]$.

Бренд виступає основою систематизації уподобань споживачів, сприйняття пропозицій різних виробників, внаслідок взаємодії уявлень про значущість якостей для даної товарної групи, ціни, інформації з реклами, спілкування з іншими людьми, ціни і ін. [16, с. 37]. Для більшості світових компаній бренд - це додаткове джерело дохідності, але водночас в балансі це не відображається. Інвестиції в бренд прирівнюються до інвестицій у майбутнє компанії та в ії успіх на ринку. Сильний бренд сприяє збільшенню марочного (репутаційного) капіталу, що $є$ найціннішим активом компанії. Бренд із високою впізнаваністю дає змогу скорочувати рекламні витрати [17, с. 369].

Бренд нереально сформувати на порожньому місці. Компанія повинна мати дійсно видатні досягнення і переваги, які закладають репутаційний фундамент. Процес створення репутації вимагає тривалого часу і значних грошових вкладень. Це постійний, дуже непростий процес, який неможливо застрахувати від загроз, втрат і ризиків. Створювати репутацію компанії потрібно безперервно, системно, комплексно, 
професійно, технологічно. Тільки тоді добре ім'я компанії стане приносити великі гроші - які люди заплатять за гарантію, підкріплену репутацією.

Нематеріальні активи стають обов'язковою умовою діяльності підприємств. Використання нематеріальних активів зростає 3 переходом конкуренції в нецінову форму. Для їх ефективного використання необхідно впроваджувати принципово нові способи обліку. Питання оцінки та відображення нематеріальних активів в обліку залишається до цього часу дискусійним. Як відзначає Ужва А.М. [18, с. 1373], «проблемою $є$ оцінка нематеріальних активів, створених підприємством самостійно. У цьому разі перед підприємством постає питання, як відобразити витрати на створення нематеріальних активів». Ми відносимо до таких активів: знання працівників, їх досвід, компетенції, репутацію підприємства, бренд, імідж.

У структурі активів Coca-Cola виділяють лише 4\% матеріальних, решта 96\% - це активи нематеріальні, тобто припадають на ділову репутацію компанії, іiі корпоративний імідж, репутацію бренду, керівників та ін. Цей класичний приклад демонструє, як «те, що не можна взяти до рук» дає відчутний, що обчислюється величезними сумами, фінансовий результат. Подібні реалії мимоволі змушують замислитися над тим, як систематизувати, класифікувати, створити і зміцнити ці невловимі поняття. Репутація у компанії є завжди, хоче вона того чи ні. Основне завдання - не дозволити статися стихійному формуванню репутації, зробити так, щоб відношення суспільства до компанії як можна більше відповідало бажаному.

На сьогодні, в 21 столітті, наразі відсутня єдина загальновизнана система обчислення вартості брендів, не дивлячись на те, що існує великий обсяг досліджень щодо оцінки вартості бренду та певних методик і моделей оцінки визнаними міжнародними консалтинговими компаніями. Разом з цим, бренд не відображається в балансі компанії через діючі до сьогодні міжнародні стандарти фінансової звітності (International accounting standards 38) [19]. Тобто, власник бренду має тільки віртуальне уявлення щодо його вартості, оскільки ні бухгалтерський, ні податковий облік не бачать його своїм об'єктом.

До того часу, поки не буде зафіксована певна модель обчислення вартості бренду, будь-яке обчислення вартості може підлягати критиці та наражати на сумнів щодо ії достовірності. Саме тому наразі вартість бренду відносять до нематеріальних активів, таких, що не відносяться та не використовуються у бухгалтерському та податковому обліку, але й водночас визнається як актив компанії.

Якби все ж таки вартість бренду можна було оцінити, то це приносило б безліч вигод для підприємства у будь-яких ситуаціях, а також мало вплив на ринкову вартість компанії чи підприємства.

Наведемо кількісну оцінку вартості найдорожчих брендів світу за даними міжнародного рейтингу компанії Interbrand [20, с. 1] та компанії Brand Finance [21, с.1]. Вказані дані використані в дослідженні [22, с.1458] при оцінюванні абсолютної та відносної похибок їх визначення (табл. 3).

Таблиця 3

Вартість найдорожчих брендів світу

\begin{tabular}{|l|c|c|c|}
\hline Джерело даних & Бренд & $\begin{array}{c}\text { Оцінена вартість у 2018 } \\
\text { році, млн. дол }\end{array}$ & $\begin{array}{c}\text { Точність показниної вартості } \\
\text { оціна }\end{array}$ \\
\hline Interbrand & Amazon & 100764 & 2,013 \\
& Apple & 214480 & $-3,146$ \\
& Google & 155506 & $-4,495$ \\
\hline Brand Finance & Amazon & 150811 & $-3,013$ \\
& Apple & 146311 & 2,146 \\
& Google & 120911 & 3,495 \\
\hline
\end{tabular}

Примітка. Складено автором на основі [20, с.1], [21, с.1], [22, с.1458]. 
Результати точності визначення вартості найдорожчих брендів світу автор [22, с.1459] кваліфікує як критично високий рівень похибок, тобто, низьку точність досліджуваних результатів економічних вимірювань.

Варто відзначити, що саме через протиріччя при визначенні оцінки бренду у 2010 році було прийнято міжнародний стандарт ISO 10668 «Brand valuation. Requirements for monetary brand valuation». Цей стандарт регламентує принципи та основні підходи щодо оцінки вартості бренду, як самостійного нематеріального активу.

Станом на 2019 рік вартість активів Coca-Cola становить 83,216.0 млн. доларів, але дуже важко оцінити реальну ринкову вартість, враховуючи нематеріальні активи [23].

Враховуючи наявну ситуацію у світовій економіці, ринкова ціна матеріальних активів постійно змінюється, в той час як нематеріальний актив набагато довше може втримувати свою вартість за сталих умов. Для прикладу, компанія Coca-Cola у березні 2020 року, заявила, що виробництво дієтичних напоїв залежить від китайських постачальників підсолоджувачів, які є ключовим інгредієнтом популярної дієтичної соди [24]. Компанія також попередила про можливі проблеми поставок в довгостроковій перспективі, якщо спалах COVID-19 продовжить рости, що власне може негативно відобразитися на вартості матеріальних активів.

Висновки. Досліджено, що головним результатом процесу розробки та управління брендом є збільшення доходів компанії та вплив на процес капіталізації компанії, оскільки бренд, що не здатний приносити прибуток, не має цінності незалежно від того, як цей актив розглядають споживачі. Матеріалізувати цінність бренду може тільки прибуток, отриманий від продажу брендованого товару. Доведено, що: не існує реальної моделі обчислення вартості бренду; головним фактором недосконалості оцінки вартості бренду є відірваність його від звітностей компаній та не відображення таких нематеріальних активів на балансі компаній; форс-мажорні обставини мають безпосередній вплив на вартість матеріальних активів, в той час як нематеріальні активи не втрачають свою вартість.

\section{Список використаних джерел:}

1. Аакер Д.. Создание сильных брендов. Москва: Издат. дом Гребенникова, 2003. 440 с.

2. Крейнер Стюарт, Дирлав Дез. Брэнды, которые изменили бизнес: полная коллекция величайших брэндов мира / Пер. с англ. Санкт-Петербург: «Крылов», 2004. 320 с.

3. Любашеский Ю. Брендинг в России. Маркетолог. 2003. №6. С.34-36.

4. Рудая Е. А. Бренд-менеджмент: учеб. метод. комплекс. Москва: МГИМО-Университет, 2008. $256 \mathrm{c}$.

5. Темпорад П. Эффективний бренд-менеджмент: пер. с англ. / Под ред. С. Г. Божук. Санкт-Петербург: Нева, 2004. 464c.

6. Музыкант В. Л. Формирование брэнда средствами PR и рекламы. Москва: Экономистъ, 2004. 608c. (C. 20-21).

7. Яндиев М. И. Бренд как инструмент снижения стоимости заимствований. Рынок ценных бумаг. 2007. т. 5. № 20. С. 18 - 39. URL: http:// istina.msu.ru. article

8. Кумбер С. Брэндинг / Пер. с англ. Москва: «Вильмс», 2003. 174 с.

9. American Marketing Association. More than Half of Consumers Buy or Boycott a Brand Because of Politics. URL: https://www.ama.org/publications/eNewsletters/MarketingNews-Weekly/Pages/ more-half-consumers-buy-boycott-

brand-because-politics.aspx.

10. Lisette de Vries, Sonja Gensler, and Peter S.H. Leeflang. Effects of Traditional Advertising and Social Messages on Brand Building Metrics and Customer Acquisition. Journal of Marketing: September. 2017. Vol. 81. № 5. P. 1-15.

11. Luping Sun, Xiaona Zheng, Meng Su, L. Robin Keller. Behavior Discrepancy of Foreign Versus Domestic Brands in Emerging Markets: The Relevance of Consumer Prior Knowledge. Journal of International Marketing. 2017. T. 25. № 1. P. 91-109.

12. Delphine Dion and Stéphane Borraz. Managing Status: How Luxury Brands Shape Class Subjectivities in the Service Encounter. Journal of Marketing. 2017. Vol. 81. № 5. P.67-85.

13. Токарчук В. Модель оцінки вартості бренду на базі публічних даних компанії. Економічний вісник університету. 2010. № 29/1. С. $187-190$.

14. Крамарчук С.П. Теоретичні та методичні аспекти управління брендом під час виходу на нові ринки. Глобальні та начіональні проблеми економіки. 2017. Випуск 20. С.389- 393.

15.Ковінько О.М., Оголь Д.В., Шевченко Н.О. Управління брендом у системі управління маркетинговою діяльністю підприємства. Економіка та управління підприємством. 2017. Випуск 20. С. 368 - 372.

16. Бренд-менеджмент: теорія і практика: навч. посібник / укл.: І. В. Струтинська. Тернопіль: Прінт-офіс, 2015. 204 с. 17. Назайкін О.Брендинг. URL:http://www.nazaykin.ru/_br_branding.htm.

18. Ужва А.М. Обліково-аналітичне забезпечення нематеріальних активів підприємства у сучасних умовах: стан та напрями вдосконалення. Економіка і суспільство. 2018. Випуск 19. С.1371 - 1375.

19. International Accounting Standart and 38 «Intangible Assets». URL: http://www.ifrs.org/IFRSs/IFRS-technicalsummaries/Documents/IAS38-English.pdf.

20. Interbrand Releases 2018 Best Global Brands Report. URL: https://bisiness.financialpost. com/pmn/press-releasee- 
$\mathrm{pmn} /$ business-wire-news-releases-pmn/interbrand-releases-2018-best-global-brands-report

21. Brand Finance Global 500. 2018. The annual report on the world's most valuable brands. URL: http://brandfinance.com/images/upload/brand_finance_global_500_report_2018_locked.pdf

22. Поздняков Ю.В., Садовенко Ю.П. Кількісна оцінка точності визначення вартості об'єктів інтелектуальної власності. Економіка і суспільство. 2018. Випуск 19. С. $1454-1462$.

23. Fortune Global 500. URL: https://fortune.com/fortune500/2019/coca-cola/.

24. Fortune Global 500. URL: https://fortune.com/2020/03/03/coronavirus-diet-coke/.

\section{References:}

1. Aaker D. (2003). Sozdaniye sil'nykh brendov [Building strong brands]. Moskva: Izdat. dom Grebennikova, 440 s. [in Russianl.

2. Kreyner Styuart, Dirlav Dez(2004). Brendy, kotoryye izmenili biznes: polnaya kollektsiya velichayshikh brendov mira / Per. s angl.[Brands That Changed Business: A Complete Collection of the World's Greatest Brands. from English]. SanktPeterburg: «Krvlov», 320 s. [in Russian].

3. Lyubasheskiy YU. (2003). Brending v Rossii [Branding in Russial. Marketolog - Marketer, №6, s.34-36 [in Russian].

4. Rudaya Ye. A. (2008). Brend-menedzhment: ucheb. metod. Kompleks [Brand management: textbook. method. Complex] Moskva: MGIMO-Universitet. 256s. [in Russian].

5. Temporad P.(2004). Effektivniy brend-menedzhment: per. s angl. / Pod red. S. G. Bozhuk [Effective brand management: trans. from English / Ed. S. G. Bozhukl. Sankt-Peterburg: Neva, 464s. [in Russian].

6. Muzykant V. L.(2004). Formirovanive brenda sredstvami PR i reklamy [Brand formation by means of PR and advertising]. Moskva: Ekonomist", 608s. (S. 20-21) [in Russian].

7. Yandiyev M. I.(2007). Brend kak instrument snizheniya stoimosti zaimstvovaniy [Brand as a tool to reduce the cost of borrowing]. Rynok tsennykh bumag - Stocks and bods market. t. 5. № 20. S. 18 - 39. URL: http:// istina.msu.ru. article [in Russian1.

8. Kumber S. (2003). Brending / Per. s angl [Branding / Per. from English]. Moskva: «Vil'ms», 174 s. [in Russian].

9. Amerykans'ka asotsiatsiya marketynhu. Bil'she polovyny spozhyvachiv kupuyut' abo boykotuyut' brend cherez polityku 「American Marketing Association. More than Half of Consumers Buy or Boycott a Brand Because of Politics]. URL: https://www.ama.org/publications/eNewsletters/MarketingNews-Weekly/Pages/ bil'she polovyny spozhyvachiv-kupytyboykotuvaty-brend-bo-polityka.aspx [in English].I.

10. Lizett de Friz. Sonva Hensler ta Piter S.KH. Liflanh (2017). Vplyv tradytsiynoyi reklamy ta sotsial'nykh povidomlen' na pokaznyky pobudovy brendu ta zaluchennya kliventiv Effects of Traditional Advertising and Social Messages on Brand Building Metrics and Customer Acquisition]. Zhurnal marketynhu: veresen' - Journal of Marketing: September. Vyp. 81. № 5. S. 1-15 [in English].

11. Lupinh Son, Syaona Chzhen, Men Su, L. Robin Keller (2017). Povedinka nevidpovidnosti inozemnykh ta vitchyznyanykh brendiv na rynkakh, shcho rozvyvayut'sya: aktual'nist' poperednikh znan' spozhyvachiv [Behavior Discrepancy of Foreign Versus Domestic Brands in Emerging Markets: The Relevance of Consumer Prior Knowledge]. Zhurnal mizhnarodnoho marketynhu - Journal of International Marketing. T. 25. № 1. S. 91-109 [in English].

12. Del'fina Dion ta Stefan Borraz (2017). Keruyuchyy status: yak brendy klasu lyuks formuyut' predmet klasu pid chas zustrichi z posluhamy [Managing Status: How Luxury Brands Shape Class Subjectivities in the Service Encounter]. Zhurnal marketynhu - Journal of Marketing. Vyp. 81. № 5. S. 67-85 [in Englishl.

13. Tokarchuk V. (2010)/ Model' otsinky vartosti brendu na bazi publichnykh danykh kompaniyi [Model of brand value assessment on the basis of public data of the company]. Ekonomichnyy visnyk universytetu - Economic Bulletin of the University. № 29/1. S.187 - 190 [in Ukrainian].

14. Kramarchuk S.P. (2017).Teoretychni ta metodychni aspekty upravlinnya brendom pid chas vykhodu na novi rynky [Theoretical and methodological aspects of brand management when entering new markets]. Hlobal'ni ta natsional'ni problemy ekonomiky - Global and national economic problems. Vypusk 20. S.389 - 393 [in Ukrainianl.

15.Kovin'ko O.M., Ohol' D.V., Shevchenko N.O. (2017). Upravlinnya brendom u systemi upravlinnya marketynhovoyu diyal'nistyu pidpryyemstva [Brand management in the management system of marketing activities of the enterprise]. Ekonomika ta upravlinnya pidpryyemstvom - . Economics and enterprise management. Vypusk 20. S. 368 - 372 [in Ukrainian]. 16. Brend-menedzhment: teoriya i praktyka: navch. posibnyk / ukl.: I. V. Strutyns'ka 「Brand management: theory and practice: textbook. manual / incl.: I.V Strutynskal. Ternopil': Print-ofis, 2015. 204 s. Гin Ukrainian1.

17. Nazaykin O. Brendynh [Branding. URL: http://www.nazaykin.ru/_br_branding.htm. [in Ukrainian].

18. Uzhva A.M. (2018). Oblikovo-analitychne zabezpechennya nematerial'nykh aktyviv pidpryyemstva u suchasnykh umovakh: stan ta napryamy vdoskonalennya [Accounting and analytical support of intangible assets of the enterprise in modern conditions: the state and areas of improvement]. Ekonomika i suspil'stvo - Economy and society. Vypusk 19. S.1371 - 1375 「in Ukrainian].

19. Mizhnarodnyy standart bukhhalters'koho obliku ta 38 «Nematerial'ni aktyvy» [International Accounting Standart and 38 «Intangible Assets»]. URL: http://www.ifrs.org/IFRSs/IFRS-technical-summaries/Documents/IAS38-English.pdf [in Englishl.

20. Interbrand vypuskaye Zvit pro naykrashchi svitovi brendy za 2018 rik [Interbrand Releases 2018 Best Global Brands Reportl. URL: https: //bisiness.financialpost. com/pmn/press-releasee-pmn/business-wire-news-releases-pmn/interbrandreleases-2018-best-global-brendy-zvit [in English].

21. Brand Finance Global 500. 2018. Richnyy zvit pro naytsinnishi brendy svitu [Brand Finance Global 500. 2018. The annual report on the world's most valuable http://brandfinance.com/images/upload/brand finance global 500 report 2018 locked.pdf [in English].

22. Pozdnyakov YU.V., Sadovenko YU.P. (2018). Kil'kisna otsinka tochnosti vyznachennya vartosti ob"yektiv intelektual'noyi vlasnosti [Ouantitative assessment of the accuracy of determining the value of intellectual property]. Ekonomika i suspil'stvo - Economy and society. Vypusk 19. S. $1454-1462$ [in Ukrainian].

23. Fortune Global 500. URL: https://fortune.com/fortune500/2019/coca-cola/ [in English].

24. Fortune Global 500. URL: https://fortune.com/2020/03/03/coronavirus-diet-coke/ [in English].

Дата подання публікації 17.10.2021p. 